International Journal of Biology, Pharmacy and Allied Seiences (IJBPAS) 'A Bridge Betuen Caboratory and Qnendo' WWW.ijbpas.com

\title{
MICROBIOLOGICAL STUDY OF MILK: A REVIEW
}

\section{CHAUHAN K ${ }^{1}$, ANDHARE ${ }^{2}$, MARCHAWALA $F^{2}$, BHATTACHARYA ${ }^{2}$ AND UPADHYAY $\mathbf{D}^{2 *}$}

1: Student, M. Sc. Microbiology, Parul Institute of Applied Sciences, Parul University, Post Limda, Waghodia, Gujarat, 391760

2: Assistant Professor, Parul Institute of Applied Sciences, Parul University, Post Limda,

$$
\text { Waghodia, Gujarat, } 391760
$$

*Corresponding Author: Dr. Dhwani Upadhyay; E Mail:dhwani.updhyay82123@paruluniversity.ac.in;

Tel: +919558021474

Received 22 ${ }^{\text {nd }}$ Jan. 2021; Revised 24 ${ }^{\text {th }}$ Feb. 2021; Accepted $25^{\text {th }}$ March 2021; Available online $1^{\text {st }}$ April 2021

https://doi.org/10.31032/IJBPAS/2021/10.4.1036

\section{ABSTRACT}

Here, we tend to review what's familiar concerning the microorganisms gift in milk, together with milk from cows, sheep, goats and humans. Milk, because of its high nutritionary content, will support a chic microbiota. These microorganisms enter milk from a spread of sources and, once in milk, will play variety of roles, like facilitating dairy farm fermentations (e.g. Lactococcus, eubacterium, eubacterium, Propionibacterium and flora populations), inflicting spoilage (e.g. bacteria genus, true bacteria, true bacteria and different spore-forming or thermoduric microorganisms), promoting health (e.g. lactobacilli and bifidobacteria) or inflicting illness (e.g. Listeria, Salmonella, escherichia, Campylobacter and mycotoxin-producing fungi). there's additionally concern that the presence of antibiotic residues in milk results in the event of resistance, significantly among unhealthful microorganism. Here, we tend to comprehensively review these topics, whereas comparing the approaches, each culture-dependent and cultureindependent, which might be taken to analyze the microbic composition of milk.

Keywords: Dairy; spoilage; safety; health; probiotic; milkborne pathogens 


\section{INTRODUCTION}

Milk is that the lacteal secretion obtained by the entire milking of class animals. thanks to its high biological process worth for people in general, it's a big food of nutrition of large population on earth. once temperature is appropriate for growth of microorganisms, the milk seems as a wonderful medium for his or her growth. The milk is contaminated terribly simply if it's handled carelessly and created unhygienically ends up in its early spoilage [1, 2].

Some of these nutrients square measure directly on the market to any or all microorganisms, whereas others square measure provided following the metabolism of major compo- nents by specific populations to unharness parts and metabolites that square measure utilized by others [3]. it's usually accepted that the carboxylic acid microorganism (LAB), a bunch of microorganism that ferment disaccharide to nurse, square measure a dominant population in bovine, goat, sheep and buffalo milk, before pasteurization. the foremost common workplace genera in milk embrace Lactococcus, eubacteria, Leucocyanobacteria, eubacterium and Enterococcus. Psychrotrophic populations, that significantly establish themselves during cold storage, are a significant part and oft embrace bacteria genus and Acinetobacter spp. different strains of non-LAB genera are encountered in milk, furthermore as varied yeasts and moulds [4]. Human milk on the opposite hand is usually domi- nated by eubacterium, staph, eubacteria and Bifidobacterium spp. [5]. Probiotics live microorganisms that square measure useful to health once consumed. Milk and milk merchandise square measure typically related to probiotic microorganism, which give supplements for the useful maintenance of the viscus system [6].

There has been associate degree increasing attention within the use of various strains of workplace as probiotics, in the main Lactobacilli and Bifidobacteria that square measure residents of the commensal microorganism in thegut of human showing sensible therapeutic functions [7]. they will manufacture antimicrobial substances (e.g.: organic acid, peroxide and bacteriocins) which may influence the expansion of the potential harmful microorganisms.

\section{THE MICROBIAL COMPOSITION OF}

\section{VARIOUS MILK SORT}

Although the big production of commercially made milk worldwide comes from cows, there area unit variety of alternative animal sources of milk that's used for human 
consumption. These embody quite common sources like goats, sheep, buffalo and alternative utilised in additional specific regions like even-toed ungulate milk in arfican and arab countries and yak milk.

\section{Cow's milk}

Cow's milk is made in large scale. variety of alternative Microogranism will be gift in important proportions. These embody Psychrotrophs, like bacteria genus, Acinecobacter and Aeromonas spp. that fluourish throughout cold storage [8]. Recently applied high-throughput within the microorganism population of raw cow's milk that was to be used for cheese production (9) our analyses indicate that the northermoduric bacterium that area unit gift among these population area unit doubtless to be in a very broken, nonculturable kind.

\section{Goat's milk}

Goat's milk production represents regarding a pair of.1\% of worldwide milk production [10]. It's a very important artefact that has gained multiplied interest as an alternate to cow's milk, thanks to proof that it's doubtless to induce allergies. Goats milk additionally disagree from cow's and sheep's milk by virtue of getting bigger levels of iron diversity [11] still as containing smaller fat globules, having the next content of fatty acids and forming a softer curd throughout ulterior fermentation, successively resulting in bigger edibleness [12].

Goats milk is most often used for cheese creating typically at fain level or in tiny dairies. it absolutely was relied on the utilization of selective microbiological media, spp analysis still as fragment length polymorphism(RFLP) typewriting of isolates to look at the microbic diversity of 118 goats milk samples taken from goats milk samples taken from one herds thoughout one lactation year to reveal the presence of a various microorganism population within the milk [13]. additionally to microorganisms unremarkably encountered in milk, like those listed on top of some species were known that aren't generally related to goats milk or that had antecedently solely been related to goats milk or that had antecedently solely been related to cheeses, together with variety of a corynobacteria and brachybacteria. Whereas these variation will be attributed to distinction in feed, the authors prompt that alternative factors like climate and the and therefore the and additionally the \} health of the animal were also vital [13].

\section{Sheep milk}

Sheep milk is never consumed however still constitutes c. $1.3 \%$ of worldwide milk production because it is usually used throughout Europe within the development $f$ 
cheese. Studies assessing the impact of storing sheep milk at refrigeration temperature highlighted will increase in Psychrophiles, however additionally in Mesophiles. Unsurprisingly, the Theromduric population didn't increase.

These general trends are full of temperature and also the length of storage. Alternative bacterium that is detected occasionally will embody organism of concern from milk safety perspective together with E.coli, Salmonella, coccus aureus, Bacilli and eubacteria [14]. In populations of Streptococci and S.aureus there was a rise and a decrease in counts, severally in regions wherever the milk was additional acidic and nutrient levels were lower [15].

Some insight into the biology of sheep milk was additionally provided by a recent study of the milk cheese, Oscypek that is factorymade while not a starter culture [16]. As this naturally hard milk cheese it's doubtless that these cheese- associated bacterium were additionally gift within the corresponding milk. This approach additionally reveled variety of minor population together with Fetragenococcus halophilus, eubacteria, Salivarius, S.thermophilus and eubacteria vertibularis. A high output sequencing-based approach revalved the presence of forty totally different genera together with six kind the order Lactobacillales that grooved ninety seven of appointed sequences.

The benefits of using this technology were once more highlighted once antecedently unmarked populations of Kocuria, Saguibacter, Flavobacteria, Thryseobacterium, Exigouobacterium, Staphulococcus and Chromonalobacter were defected. Notably a substantial proporation 2 hundredth of sequence reads couldn't be appointed, and then the identity of those bacterium and also the importance of the opposite sub populations can needed futher attention [16].

\section{Bluffalo milk}

Buffalo milk is consumed in varied countries round the world with India and Islamic Republic of Pakistan being the very best shoppers. it's not as common in Europe, however it will have a very important market in some Mediterranean countries wherever it's utilize in creating ancient cheese cheese. The microbic content of raw buffalo milk has been assessed, through culturing, and located to contain an oversized population of laboratory, together with Lactococci and Lctohaillious, as can as Coliforms. E.coli, S.aureus and microorganism endospores, light that technologically relevant bacterium area unit gift, microorganisms of concern with relevancy quality and safety also can be found [17].More recently, high output 
sequencing has been applied to identity the microorganism populations gift in buffalo milk and throughout the manufacture of cheese cheese[18].

\section{Technologically relevant microorganism of} milk

Raw milk will contain a various microorganism population. Several such microorganism will contribute subse- quently to natural fermentations. In some things, specific strains are therefore eminent during this regard that they need been isolated from milk and consciously adscititious as starters or adjuncts designed to confer fascinating traits on soured product. this will be significantly impor- tant in things wherever rules need the utilization of change integrity milk, and thus, the re-introduction of farm microorganisms will complete the removal of com- table populations and therefore the associated adverse impact on the flavour of resultant product.

\section{Lactococcus}

Lactococcus lactis ssp. lactis biovar diacetylactis is additionally recognised for its production of flavour-developing compounds [19]. These microorganisms ar distinguished from each other on the idea of essential amino acid and change state usage, growth temperature and salt tolerance. A comparison of twenty Lactococcus lactis strains, ten of the ssp. lactis composition and ten of the ssp. cremoris composition, confirmed 2 major taxonomic group lin- eages that were distinguished on the idea of the presence or absence of 4571 cistron orthologs. Thus, it's calculable that these phenotypically similar taxonomic group diverged c. seventeen million years past [20]. microogranism of Lactococcus lactis ssp. lactis IL1403 unconcealed that every one glorious genes needed for energy metabolism were gift, together with variety of cistrons concerned in fermen- tation yet as a completely unique gene, poxL, encryption pyruvate enzyme, which can play a task in change between ferthought modes. xliii insertion parts were identified, the distribution of that suggests that recent recombination between 2 closely connected genomes might have occurred [21]. Sequencing of Lacto- cocci lactis ssp. cremoris MG1363 unconcealed some similari- ties to strain IL1403, together with chemical change systems and genes related to the usage of milk sugar.

\section{Lactobacillus}

The genus Lactobacillus is extremely various and, per the foremost recent estimations, consists of 174 completely different species and twenty seven taxonomic group (www.bacterio.cict.fr). Lactobacilli will be found in wealthy, carbohydrate-containing 
niches, together with those related to plants, animals, provender and milk [22]. associate degree ever bigger understanding of true bacteria biology has crystal rectifier to the utilization of strains of true bacteria for associate degree increasing vary of commercial farm applications. specifically, their proteo- lytic activity and talent to supply aroma compounds and exopolysaccharides will contribute to the standard and nutritionary worth of farm product . Lactobacilli that ar of specific importance among the farm business ar L. helveticus, L. delbrueckii ssp. bulgaricus and L. delbrueckii ssp. lactis (the latter 2 species are going to be cited as L. bulgaricus and true bacteria lactis hereafter). true bacteria helveticus was first delineate by Orla- writer in 1919 as associate degree isolate from associate degree Emmentaler cheese however it's since been evident that representatives of this species ar usually isolated from milk and milk based mostly product [23]. True bacteria helveticus includes a range of traits that ar fascinating with regard to cheese production. These embrace fast lysis of the strains, which ends within the unharness of animate thing enzymes and a discount in bitterness and inflated inflated notes in cheese [24]. True bacteria helveticus is additionally characterized by its ability to grow at comparatively high temperatures $[\mathbf{2 5}$, 26] and is that the most chemical change of the workplace oft employed in the manufacture of farm product. The discharge of free fatty acids following lipolysis introduces vital vital compounds [27]. Ordination sequencing of L. helveticus DPC4571, a cheese isolate, unconcealed that the presence of a high share of pseudogenes that ar related to loss-of-function events and presumptively presumptively adaptation to the farm niche [28]. The expansion of $L$. helveticus in milk depends on a fancy system of chemical change enzymes, that put together modify strains to access essential amino acids [29]. There ar many true bacteria increase in range throughout the manufacture of farm product and might become significantly dominant throughout the ripening of cheese.

\section{Streptococcus}

The bacteria genus consists of ninety-seven species and seventeen sub- species (www.bacterio.cict.fr). though several genera of streptococci ar unhealthful, S. thermophilus carries a 'GRAS' standing [30] and is usually isolated from farm environments, together with milk, natural starter cultures and cheese curds [31-33]. Strains of S. thermophilus have additionally 
been detected within the teats of cows, cowsheds and farm facilities $[34,35]$.

\section{Leuconostoc}

The genus Leuconostoc consists of twentythree species and four subspe- cies (www.bacterio.cict.fr). Leuconostoc spp. ar oft related to material, but some, and specifically the species mesenteroides and pseudomesenteroides, are found in milk. However, it's potential that this is often because of their introduction throughout the gathering of milk or subse- quent storage and process. Notably, during this regard, Leuconostoc spp. have the power to survive on surfaces, tools and pasteurisers for long periods of your time and to resist heat treatments and refrigeration temperatures [36].

\section{CONCLUSION}

The microbic community at intervals milk is advanced. The dominant, and tone, microorganisms gift in milk will have a spread a spread on the flavour, style and texture of raw milk-derived product. Variety of those microorganisms even have the potential to contribute to health through the assembly of antimicrobials or possessing different probiotic-associated traits. Through trendy genomics-based analysis, it's been established that several of those microorganisms became custom-made to take advantage of niches from varied sources, as well as plant and gut environments, through genomic evolution and cistron gain and/or loss. Despite the beneficial impact of the many milk-associated microorganisms from a flavour, technological or healthrelated perspective, it's clear that there may be may be related to the consumption of milk and raw milk-derived product or, additional additional, of the pathogens that may be found in this. whereas several of those microorganisms gain entry to the milk from instrumentality and/or personnel, animal disease pathogens may also be introduced into milk from unhealthy animals. As a consequence of this risk, sterilization or different treatments square measure utilized to get rid of disease-causing microorganisms. Within the food trade, the negative impact of removing science lab and different bacterium on resultant food fermentations has been selfaddressed for a few time through their reintroduction within the kind of starter and adjunct cultures.

\section{ACKNOWLEDGEMENT}

It's our privilege and honour to express our sincerest gratitude to the Parul University, Vadodara, Gujarat for providing me all the necessary support and facilities including state of the art infrastructural facilities with advanced technological scientific laboratories 
and everything else that was required to carry out this work.

\section{REFERENCE}

[1] Prajapati JB. Fundamentals of Dairy Microbiology Aktaparakashal Nadiad Gujarat, India, 1995, 2(4) 4-45.

[2] Schmidt GH and Van Vlerck LD. Principles of Dairy Science Surjeet Publlication, New Delhi, 1982, 2(4) 3-5.

[3] Frank JF (1997) Milk and dairy products. Food Microbiology Fundamental and Frontiers (Doyle P, Beuchat R \& Montville J, eds), pp. 169-186. ASM Press, Washington, DC.

[4] Quigley L, O’Sullivan O, Beresford TP, Ross RP, Fitzgerald GF \& Cotter PD (2011) Molecular approaches to analysing the microbial composition of raw milk and raw milk cheese. Int J Food Microbiol 150:81-94.

[5] Martın R, Heilig HG, Zoetendal EG, Jimenez E, Fernandez L, Smidt H \& Rodriguez JM (2007) Cultivationindependent assessment of the bacterial diversity of breast milk among healthy women. Res Microbiol 158: 31-37.

[6] Tambekar, D.H. and Bhutada, S.A. (2010). An evaluation of probiotic potential of Lactobacillus $s p$. from milk of domestic animals and commercial available probiotic preparations inprevention of enteric bacterial infections. Recent Research in Science and Technology, 2(10): 82-88.6.

[7] Lavanya, B., Sowmiya, S., Balaji, S. and Muthuvelan, B. (2011). Screening and characterization of lactic acid bacteria from fermented milk, British Journal of Dairy Sciences, 2(1): 5-10.

[8] Raats D, Offek M, Minz D \& Halpern M (2011) Molecular analysis of bacterial communities in raw cow milk and the impact of refrigeration on its structure and dynamics. Food Microbiol, 28 37(2013): 465-471.

[9] Masoud W, Vogensen FK, Lillevang S, Abu Al-Soud W, Sorensen SJ \& Jakobsen M (2012) The fate of indigenous microbiota, starter cultures, Escherichia coli, Listeria innocua and Staphylococcus aureus in Danish raw milk and cheeses determined by pyrosequencing and quantitative real time (qRT)-PCR. Int J Food Microbiol, 37(2013) 153: 192-202. 
[10] Tsakalidou E \& Odos I (2012) Microbiota of Goat's Milk and Goat's Milk Cheese. Proceedings of First Asia Dairy Goat Conference, pp. 40-41. University Putra Malaysia and the Food and Agricultural Organisation on the United Nations (FAO), Kuala Lumpur, Malaysia, 37(2013).

[11] Boyazoglu $\mathrm{J}$ \& Morand-Fehr $\mathrm{P}$ (2001) Mediterranean dairy sheep and goat products and their quality: a critical review. Small Rum Res, 40 37(2013):1 -11.

[12] Klinger I \& Rosenthal I (1997) Public health and the safety of milk and milk products from sheep and goats. Rev Sci Tech 16 37(2013): 482.

[13] Callon C, Duthoit F, Delbes C, Ferrand M, Le Frileux Y, De Cremoux R \& Montel MC (2007) Stability of microbial communities in goat milk during a lactation year: molecular approaches. Syst Appl Microbiol 30 37(2013): 547-560.13.

[14] Fotou K, Tzora A, Voidarou C et al. (2011) Isolation of microbial pathogens of subclinical mastitis from raw sheep's milk of Epirus (Greece) and their role in its hygiene. Anaerobe 17 37(2013): 315-319.

[15] Yabrir B, Hakem A, Laoun A, Labiad M, Nazek E-G, Hamadi A \& Abderrahmane M (2013) Does the aridity of Algerian Steppe affect the Ewe's raw milk quality? Bull Univ Agric Sci Vet Med Cluj Napoca 69 37(2013):1 -9.

[16] Alegria A, Szczesny P, Mayo B, Bardowski J \& Kowalczyk M (2012) Biodiversity in Oscypek, a traditional Polish cheese, determined by culture-dependent and -independent approaches. Appl Environ Microbiol 78 37(2013): 1890-1898.

[17] Ercolinic D, Russo F, Ferrocino I \& Villani F (2009) Molecular identification of mesophilic and psychrotrophic bacteria from raw cow's milk. Food Microbiol 26 37(2013): 228-231.

[18] Ercolini D, De Filippis F, La Storia A \& Iacono M (2012) "Remake" by high-throughput sequencing of the microbiota involved in the production of water buffalo mozzarella cheese. Appl Environ Microbiol 78 37(2013): 8142-8145. 
[19] Hugenholtz J \& Starrenburg MJ (1992) Diacetyl production by different strains of Lactococcus lactis subsp. lactis var. diacetylactis and Leuconostoc spp. Appl Microbiol Biotechnol 38 37(2013): 17-22.

[20] Bolotin A, Quinquis B, Renault P et al. (2004) Complete sequence and comparative genome analysis of the dairy bacterium Streptococcus thermophilus. Nat Biotechnol 22 37(2013): 1554-1558.9.

[21] Bolotin A, Wincker P, Mauger S et al. (2001) The complete genome sequence of the lactic acid bacterium Lactococcus lactis ssp. lactis IL1403. Genome Res 11 37(2013): 731-753.10.

[22] Bernardeau M, Vernoux JP, HenriDubernet S \& Gueguen M (2008) Safety assessment of dairy microorganisms: the Lactobacillus genus. Int J Food Microbiol 126 37(2013): 278-285.

[23] Quigley L, O'Sullivan O, Beresford TP, Ross RP, Fitzgerald GF \& Cotter PD (2011) Molecular approaches to analysing the microbial composition of raw milk and raw milk cheese. Int $\mathrm{J}$ Food Microbiol 150 37(2013):81-84.

[24] Broadbent J, Cai H, Larsen R et al. (2011) Genetic diversity in proteolytic enzymes and amino acid metabolism among Lactobacillus helveticus strains. J Dairy Sci 94 37(2013): 4313-4328.

[25] Kiernan RC, Beresford TP, O'Cuinn G \& Jordan KN (2000) Autolysis of lactobacilli during Cheddar cheese ripening. Irish J Agric Food Res 39 37(2013): 95-106.

[26] Hannon JA, Wilkinson MG, Delahunty CM, Wallace JM, Morrissey PA \& Beresford TP (2003) Use of autolytic starter systems to accelerate the ripening of Cheddar cheese. Int Dairy J 13 37(2013): 313-323.

[27] Hickey DK, Kilcawley KN, Beresford TP \& Wilkinson MG (2007) Lipolysis in cheddar cheese made from raw, thermized, and pasteurized milks. J Dairy Sci 90 37(2013): $47-56$.

[28] Callanan M, Kaleta P, O'Callaghan $\mathrm{J}$ et al. (2008) Genome sequence of Lactobacillus helveticus, an organism distinguished by selective gene loss and insertion sequence 
element expansion. J Bacteriol 190 37(2013): 727-735.28.

[29] Christensen JE, Dudley EG, Pederson JA \& Steele JL (1999) Peptidases and amino acid catabolism in lactic acid bacteria. Anton Leeuw Int JG 76 37(2013): 217-246.

[30] Facklam R (2002) What happened to the streptococci: overview of taxonomic and nomenclature changes. Clin Microbiol Rev 15 37(2013): 613.13 .

[31] Duthoit F, Callon C, Tessier L \& Montel MC (2005) Relationships between sensorial characteristics and microbial dynamics in 'Registered Designation of Origie' Salers cheese. Int J Food Microbiol 103 37(2013): 259-270.14.

[32] Randazzo CL, Vaughan EE \& Caggia C (2006) Artisanal and experimental Pecorino Siciliano cheese: microbial dynamics during manufacture assessed by culturing and PCR-DGGE analyses. Int $\mathrm{J}$ Food Microbiol 109 37(2013): 18.15 .

[33] Santarelli M, Gatti M, Lazzi C, Bernini V, Zapparoli GA \& Neviani E (2008) Whey starter for Grana
Padano cheese: effect of technological parameters on viability and composition of the microbial community. J Dairy Sci 91 37(2013): 883-891.16.

[34] Vacheyrou M, Normand A-C, Guyot P, Cassagne C, Piarroux R \& Bouton Y (2011) Cultivable microbial communities in raw cow milk and potential transfers from stables of sixteen French farms. Int $\mathbf{J}$ Food Microbiol 146 37(2013): 253262.17 .

[35] Braem G, De Vliegher S, Verbist B, Heyndrickx M, Leroy F \& De Vuyst L (2012) Culture-independent exploration of the teat apex microbiota of dairy cows reveals a wide bacterial species diversity. Vet Microbiol 157 37(2013): 383390.18 .

[36] Hemme D \& Foucaud-Scheunemann C (2004) Leuconostoc, characteristics, use in dairy technology and prospects in functional foods. Int Dairy J 14: 467494. 